\title{
Trace Elements in Dominant Species of the Fenghe River, China: Their Relations to Environmental Factors
}

\author{
Yang Yang, Zhengchao Zhou, Yanying Bai, * Wentao Jiao, and Weiping Chen
}

\begin{abstract}
The distribution of trace elements (TEs) in water, sediment, riparian soil and dominant plants was investigated in the Fenghe River, Northwestern China. The Fenghe River ecosystem was polluted with $\mathrm{Cd}, \mathrm{Cr}, \mathrm{Hg}$ and $\mathrm{Pb}$. There was a high pollution risk in the midstream and downstream regions and the risk level for $\mathrm{Cd}$ was much higher than that of the other elements. The average values of bioconcentration coefficient for $\mathrm{Cd}$ and $\mathrm{Zn}$ were 2.21 and 1.75 , respectively, indicating a large accumulation of $\mathrm{Cd}$ and $\mathrm{Zn}$ in the studied species. With broad ecological amplitudes, Portulaca oleracea L., Artemisia argyi Levl. et Vant., Phragmites communis Trin., and Polygonum hydropiper L. had the greatest TE concentrations in aboveground and belowground biomass of the studied species and were potential biomonitors or phytoremediators for the study area. Multivariate techniques including cluster analysis, correlation analysis, principal component analysis, and canonical correspondence analysis were used to analyze the relations between TE concentrations in plants and various environmental factors. The soil element concentration is the main factor determining the accumulation of TEs in plants. The co-release behavior of common pollutants and TEs drove the accumulation of $\mathrm{Hg}, \mathrm{Cd}$, and $\mathrm{As}$ in the studied plants. Significant enrichment of some elements in the Fenghe River has led to a decline in the biodiversity of plants.
\end{abstract}

\section{Core Ideas}

- Trace elements posed high ecological risk in the Fenghe River system.

- Four native species could be used for phytoremediation.

- Dissolved $\mathrm{NH}_{3}-\mathrm{N}, \mathrm{NO}_{3}-\mathrm{N}, \mathrm{TN}$, and TP drove elemental uptake by plants.

- Soil elements and soil pH had major effect on plants uptake of elements.

- Plant diversity was sensitive to the high level trace elements in the water habitats.

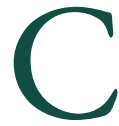

ONTAMINATION of river systems with trace elements (TEs, also termed heavy metals, trace metals) is of great concern on a world scale and in China particularly with the rapid development of industry (Rai, 2008; Yi et al., 2011). When discharged into rivers, TEs can be strongly accumulated and biomagnified in water, sediment, riparian soil, and plants, which causes the deterioration of water habitats, and impairs human health (Zhao et al., 2010; Fu et al., 2014). In the river ecosystem, plants are considered as an important component, for they act not only as the food source but also as the carriers or accumulators of hazardous element pollutants (Rai, 2008; Pandey et al., 2015). To address the phytotoxicity of TEs, plants resort to a range of mechanisms to control uptake, enrichment, and translocation of some dangerous elements; thus, plants are commonly characterized as excluders, accumulators, and monitors (Tang, 2006; Leung et al., 2007; Ali et al., 2013). Apparently, plants with a better ability to adjust to toxicity are better candidates for bioindication or phytoremediation, especially when the plants concerned are native and dominant (Shen et al., 2002; Pandey et al., 2015). These species play a critical role in local aquatic diversity preservation, and they response better, survive easily, and could recover soil quality, functionality, and sustainability in the situ-remediation of polluted areas (Ali et al., 2013; Salazar and Pignata, 2014).

The accumulation of TEs in plants is not an isolated factor, but interacts with various environmental factors such as the physicochemical properties of different media, elemental characteristics that control adsorption, TE concentrations in the environment, and anthropogenic activities (Kirkham, 2006; Pandey, 2015). Therefore, element concentrations in plants near the river can provide time-integrated information about the quality of the river system, and reflect a combined effect of biological, physical, and chemical processes occurring in aquatic habitats (Rai, 2008). Investigating the element concentrations in dominant species and environment factors is beneficial in revealing the intensity and range of regional contamination and to assess the impact of TEs on the local environment (Peralta-Videa et al., 2009; Rascio
Copyright $\odot$ American Society of Agronomy, Crop Science Society of America, and Soil Science Society of America. 5585 Guilford Rd., Madison, WI 53711 USA.

All rights reserved.

J. Environ. Qual. 45:1252-1258 (2016)

doi:10.2134/jeq2015.03.0126

Supplemental material is available online for this article.

Received 15 Sept. 2015.

Accepted 29 Nov. 2015

*Corresponding author (baiyy@igsnrr.ac.cn).
Y. Yang, W. Jiao, and W. Chen, State Key Laboratory of Urban and Regional Ecology, Research Center for Eco-Environmental Sciences, Chinese Academy of Sciences, Beijing 100085, China; Z. Zhou, College of Environment and Tourism, Shaanxi Normal Univ., Xi'an Shaanxi 710062, China; Y. Bai, Institute of Geographic Sciences and Natural Resources Research, Chinese Academy of Sciences, Beijing 100101, China. Assigned to Associate Editor Scott Young.

Abbreviations: $\mathrm{BC}$, bioconcentration coefficient; $\mathrm{TC}$, translocation coefficient; $\mathrm{TE}$, trace element. 
and Navari-Izzo, 2011). However, few studies have focused on the interaction of TE uptake by plants with environmental characteristics.

The Fenghe River is one of the major sources of water supply for Xi'an, northwestern China. In recent decades, the Fenghe River has suffered a serious pollution risk owing to the rapid urbanization and over-exploitation water resources (Wang et al., 2013). However, there have been no reports on TE concentrations in the Fenghe River basin. In this study, we investigated the pollution status of TEs in water, sediment, riparian soil, and the dominant plant species of the Fenghe River as well as to assess TE concentrations in plants in relations to various environmental factors. Results can provide valuable information toward understanding the pollution characteristics and may help manage the pollution risk in the Fenghe River ecosystem.

\section{Materials and Methods}

\section{Study Area}

The Fenghe River $\left(33^{\circ} 50^{\prime}-34^{\circ} 20^{\prime} \mathrm{N} ; 108^{\circ} 35^{\prime}-109^{\circ} 09^{\prime} \mathrm{E}\right)$ originates south of Xi'an in the northern slopes of the Qinling Mountains, extends to $81 \mathrm{~km}$ in Shaanxi province, and has an annual mean discharge of $2.58 \times 10^{10} \mathrm{~m}^{3} \mathrm{yr}^{-1}$ with significant seasonal variations. As the largest tributary in the southern coast of the Weihe River in the Yellow River basin, the Fenghe River drains an area of $1460 \mathrm{~km}^{2}$, transitioning between semiarid and subhumid zones in the northwest parts of China. Field surveys and sampling were conducted at 16 sites along the Fenghe River in 2011, including 4 sites situated in the headwater, 6 sites situated in the midstream, and 6 sites situated in the downstream stretch of the river (Fig. 1).

\section{Field Sampling}

At each site, three water samples were collected from the middle, and both sides of the river in $1 \mathrm{~L}$ acid washed polyethylene bottles. Five surface sediment samples $(0-2 \mathrm{~cm}$ depth) and one deep sediment sample $(30 \mathrm{~cm})$ were collected with a gravity corer $\left(60 \mathrm{~cm}\right.$ length, $6 \mathrm{~cm}$ i.d.) within an area of $2.5 \mathrm{~m}^{2}$; three riparian topsoil samples $(0-20 \mathrm{~cm}$ depth) were collected with a stainless steel spade.

For plant species sampling, 8 to 10 plots with circular quadrats of 0.5 -m radius were randomly set at each site. The density, height, and coverage of plant species were investigated and recorded. Then, 5 to 30 plant samples were collected and stored in sealed polyethylene bags. All samples were stored in a cooled box until analysis. In total, 36 water samples, 96 sediment samples, 54 soil samples, and 196 plant samples were collected.

\section{Chemical Analysis}

Water samples were first filtered through a $0.22-\mu \mathrm{m}$ filter (Millipore) membrane. Then filtered samples were analyzed for dissolved element concentration while membranes were kept at $-20^{\circ} \mathrm{C}$ for particulate element concentration extraction. Sediment and soil samples were air dried, sieved through a 2-mm nylon mesh, and milled for further analysis. Plant samples were washed with tap water, rinsed with deionized water four to five times, and then separated into aboveground and belowground biomass. After that, plant samples were dried in an oven at $60^{\circ} \mathrm{C}$ and milled for chemical analysis.

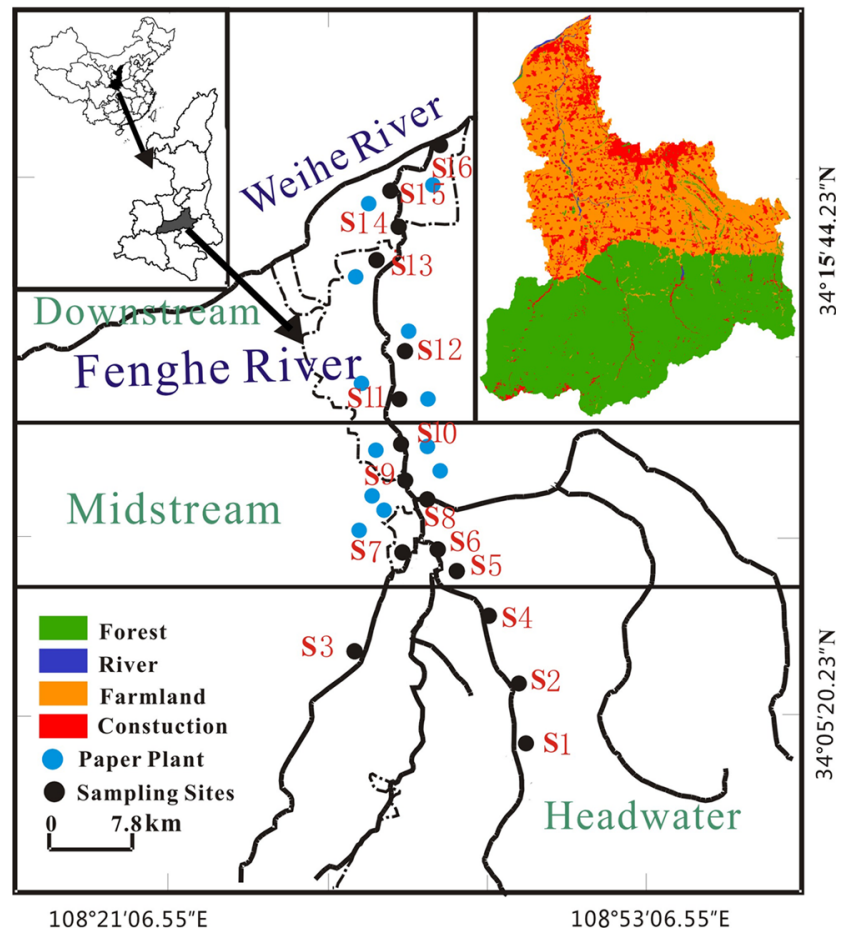

Fig. 1. Location of the study area and sampling sites with land-use types shown in the top right corner.

For the measurement of As and $\mathrm{Hg}$ concentrations, samples were digested with aqua regia. For other elements, the samples were digested with a mixture of $\mathrm{HCl}, \mathrm{HNO}_{3}, \mathrm{HF}$, and $\mathrm{HClO}_{4}$ (Zhao et al., 2010). Concentrations of As and $\mathrm{Hg}$ were measured by atomic fluorescence spectrometry (Rayleigh AF-610B, Beijing, China), concentrations of $\mathrm{Cr}, \mathrm{Cu}, \mathrm{Ni}$, and $\mathrm{Zn}$ were determined by ICP-AES (PerkinElmer DV4300), and concentrations of $\mathrm{Cd}$ and $\mathrm{Pb}$ were determined by ICP-MS (Agilent $7500 \mathrm{CX}$ ). The accuracy of the analysis was assessed by the use of certified reference standards for water (GSBZ50004-88 for As, GSB071185-2000 for Cd, GSB07-1187-2000 for Cr, GSB07-11822000 for Cu, GSBZ50016-90 for Hg, GSB07-1186-2000 for $\mathrm{Ni}$, GSB07-1183-2000 for Pb, and GSB07-1184-2000 for Zn), soil (GSS-12), sediment (GSD-1) and plants (GBW07604). The recovery of each element was in the range of 90.0 to $104.2 \%$ for water (not detected for $\mathrm{Hg}$ ), 85.7 to $110.9 \%$ for sediments, 84.3 to $108.7 \%$ for soil, and 82.4 to $103.8 \%$ for plants, respectively. Duplicates were analyzed on $10 \%$ of all samples and the standard deviations $(\mathrm{SD})$ were within $5 \%$ of the mean.

\section{Environmental Factors}

The hydrological conditions of the Fenghe River were measured in the field, including width, depth, velocity, sinuosity, and gradient. For measurement of water quality indices, water temperature was determined in the field, and $\mathrm{pH}$, electrical conductivity, oxidation reduction potential, dissolved oxygen, ammonia nitrogen $\left(\mathrm{NH}_{4}-\mathrm{N}\right)$, nitrate nitrogen $\left(\mathrm{NO}_{3}-\mathrm{N}\right)$, and chemical oxygen demand were determined according to standard methods for water analysis (Wang et al., 2013). Basic chemical properties of soil and sediments including $\mathrm{pH}$, loss on ignition, total organic carbon, and particle size were determined in the laboratory following standard analytical methods ( $\mathrm{Lu}, 2000)$. 
Additional information on these environmental factors is provided in Supplemental Table S1.

\section{Statistical Analysis}

The ecological risks of dangerous elements in water, sediment, and riparian soil were evaluated by fuzzy synthetic methods (Supplemental Table S2). The Important value, the Simpson diversity index, and the Shannon-Weiner diversity index were used to evaluate the growth status and importance of species in its community on the basis of species proportional abundance in the study area (Simpson, 1949; Peet, 1975). The variation coefficient of the Shannon-Weiner diversity index was used to measure the exactness of dominant species identification (He et al., 2002). The bioconcentration coefficient (BC) and translocation coefficient (TC) were applied to assess the ability of plants to enrich and transfer TEs (Ali et al., 2013). Details of these methods are provided in the supplemental material.

The land-use pattern was sourced from Landsat TM images in ENVI 4.1 and ArcGIS 10.0. Correlation analysis, hierarchical cluster analysis, factor analysis, and risk assessment were performed with Matlab version 7.14 (MathWorks, 2012). Canonical corresponding analysis was applied with Canoco version 4.5 (Ter Braak and Smilauer, 2002). Concentrations of TEs were transformed into logarithmic values to elucidate the normal distribution characteristics and avoid distortions in the data distribution and low levels of significance (Shapiro-Wilk determinations at $p<0.05)$.

\section{Results and Discussion}

\section{Trace Elements in Aquatic Habitats}

Among the eight elements we surveyed, only a few exceeded the national standards (SEPAC, 1990, 2002). Table 1 summarizes the concentrations of four high level elements (mean \pm SD) in water, sediments, and riparian soil from the Fenghe River and other major rivers. The total concentrations of $\mathrm{Cd}$ and $\mathrm{Cr}$ in water were $0.015 \mathrm{mg} \mathrm{L}^{-1}$ and $0.519 \mathrm{mg} \mathrm{L}^{-1}$, which are 3.0 - and 10.4-fold greater than the water guidelines, respectively (SEPAC, 2002). Higher concentrations of $\mathrm{Cd}, \mathrm{Cr}, \mathrm{Hg}$, and $\mathrm{Pb}$, were found in the sediment and riparian soil. In particular, the concentration of $\mathrm{Cd}$ and $\mathrm{Hg}$ in sediment, and concentration of $\mathrm{Hg}$ in soil were 7.8-, 9.7-, and 7.9-fold greater than the background values, respectively (SEPAC, 1990). Compared with other major rivers in China, the concentrations of most elements in the Fenghe River were much lower. Compared with rivers around the world, the element levels in sediment and soil were relatively low, and the element levels in water were much higher.

Concentrations of TEs in the Fenghe River showed a large variation. For water samples, the elements $\mathrm{As}, \mathrm{Cd}, \mathrm{Cu}, \mathrm{Ni}$, and $\mathrm{Zn}$ existed mainly in the particle phase, whereas $\mathrm{Pb}$ in water occurred in the dissolved phase. Spatially, the total concentrations of individual elements in water samples showed no obvious trends along the Fenghe River (Supplemental Fig. S1), as TE concentrations were affected by hydrodynamic conditions ( Fu et al., 2014). Concentrations of TEs in sediment and soil from samples near a paper factory were elevated related to other sections. Significant enrichment of $\mathrm{As}, \mathrm{Cd}, \mathrm{Cr}, \mathrm{Hg}, \mathrm{Ni}$, and $\mathrm{Zn}$ in sediment and $\mathrm{Cd}, \mathrm{Cr}, \mathrm{Hg}$, and $\mathrm{Zn}$ in soil were found midstream and downstream of the Fenghe River. Concentrations of $\mathrm{Cu}$ in sediments and soil were relatively higher in the headwaters, while the other sections had lower concentrations (Supplemental Fig. S1).

The ecological risks of TEs in the Fenghe River were evaluated by the fuzzy synthetic method. Results showed that 15 samples in water, 12 samples in sediment, and 12 samples in soil fell into the polluted class, respectively (Supplemental Table S3). Samples with high pollution risk were found in the midstream and downstream regions, in accordance with the TE distribution pattern. The risk level for $\mathrm{Cd}$ was much higher than for the other elements in water, sediment, and soil, such that $\mathrm{Cd}$ should be included in the primary pollutants list in the study region.

Table 1. Concentrations of trace elements with high levels (mean \pm SD) in the aquatic habitats of the Fenghe River in China.

\begin{tabular}{|c|c|c|c|c|c|}
\hline Media & Element & Fenghe River & Background values $\dagger$ & Rivers in Chinał & Rivers in the world§ \\
\hline & & & $-m$ & & 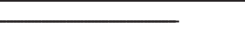 \\
\hline \multirow[t]{4}{*}{ Water } & $\mathrm{Cd}$ & $0.015 \pm 0.005$ & 0.005 & $0.170 \pm 0.015$ & $0.009 \pm 0.010$ \\
\hline & $\mathrm{Cr}$ & $0.519 \pm 0.173$ & 0.050 & $5.725 \pm 1.996$ & $0.198 \pm 0.258$ \\
\hline & $\mathrm{Cu}$ & $1.521 \pm 0.914$ & 1.000 & $1.942 \pm 2.421$ & $0.971 \pm 0.323$ \\
\hline & $\mathrm{Zn}$ & $0.065 \pm 0.032$ & 1.000 & $1.720 \pm 1.657$ & $4.255 \pm 7.909$ \\
\hline \multirow[t]{4}{*}{ Sediment } & $\mathrm{Cd}$ & $0.86 \pm 0.47$ & 0.11 & $1.66 \pm 1.64$ & $1.13 \pm 1.64$ \\
\hline & $\mathrm{Cr}$ & $75.4 \pm 11.7$ & 57.5 & $82.1 \pm 32.2$ & $76.6 \pm 10.9$ \\
\hline & $\mathrm{Cu}$ & $0.68 \pm 0.51$ & 0.07 & $0.16 \pm 0.21$ & na \\
\hline & $\mathrm{Zn}$ & $28.7 \pm 4.7$ & 22.3 & $62.2 \pm 26.9$ & $49.1 \pm 7.6$ \\
\hline \multirow[t]{4}{*}{ Soil } & $\mathrm{Cd}$ & $0.14 \pm 0.04$ & 0.1 & $0.52 \pm 0.23$ & $4.37 \pm 1.10$ \\
\hline & $\mathrm{Cr}$ & $92.1 \pm 12.5$ & 62.5 & $53.4 \pm 33.9$ & $149.5 \pm 39.5$ \\
\hline & $\mathrm{Cu}$ & $0.55 \pm 0.47$ & 0.07 & $0.05 \pm 0.07$ & na \\
\hline & $\mathrm{Zn}$ & $32.9 \pm 3.8$ & 21.4 & $28.4 \pm 13.7$ & $67.2 \pm 148.6$ \\
\hline
\end{tabular}

+ Water element background values derived from China Environmental Quality Standards for surface water (GB3838-2002, SEPAC, 2002); Soil element background values derived from the background value of soil element in the Shaanxi Province (SEPAC, 1990); Sediment element background values derived from the determined concentration of sediment samples from $30 \mathrm{~cm}$ depth in this study.

₹ Average value for the Yellow river (Nie et al., 2010; Wang et al., 2010; Bai et al., 2012), Yangtze River (Zhao et al., 2010; Song et al., 2011; Yi et al., 2011), and the Pearl River (Wong et al., 2002; Ouyang et al., 2006; Niu et al., 2009).

$\S$ Average value for the Ganges River (Sun et al., 2001; Singh et al., 2003; Singh et al., 2005), Euphrates River (Riccobono et al., 2011; Kalender and Uçar, 2013), and the Nile River (Awadallah et al., 1996; Lasheen and Ammar, 2009; Osman and Kloas, 2010). 


\section{Trace Elements in Plants}

A total of 16 dominant species from nine families belonging to perennial herb and therophytes were investigated (Supplemental Table S4). The average value of variation coefficient of the Shannon-Weiner diversity index for each species ranged from 7 to $13 \%$, indicating that the sampling scale was suitable ( $\mathrm{He}$ et al., 2002). The communities were characterized by the families of Compositae and Gramineae, with a high level of Important value (22.2 and $20.3 \%$, respectively). This distribution pattern may be related to their ability to resist drought conditions and produce easily dispersed seeds (Leung et al., 2007).

Table 2 summarizes the TE concentrations in aboveground and belowground biomass of the dominant plants. Concentrations of TEs in aboveground and belowground biomass followed the same sequence: $\mathrm{Zn}>\mathrm{Pb}>\mathrm{Cu}>\mathrm{Cr}>\mathrm{Ni}>$ As $>\mathrm{Cd}>\mathrm{Hg}$. Significant differences were found in concentrations of $\mathrm{As}(p<0.01), \mathrm{Cu}(p<0.05), \mathrm{Hg}(p<0.001)$, and $\mathrm{Pb}$ $(p<0.001)$ between aboveground and belowground biomass. Due to the low bioavailability of $\mathrm{Hg}$ (Peralta-Videa et al., 2009), the concentrations of $\mathrm{Hg}$ in the studied species were generally very low, with concentrations of 0.005 and $0.047 \mathrm{mg} \mathrm{kg}^{-1}$ in the aboveground and belowground biomass, respectively.

Concentrations of $\mathrm{Cd}$ in aboveground and belowground biomass were 0.27 and $0.31 \mathrm{mg} \mathrm{kg}^{-1}$, respectively, and both were higher than the normal concentration of Cd in plants $(0.1 \mathrm{mg}$ $\mathrm{kg}^{-1}$; Kirkham, 2006). Concentrations of $\mathrm{Cr}$ in aboveground and belowground biomass were 8.0- and 9.6-fold greater than the normal concentration of $\mathrm{Cr}$ needed for plant growth (below $0.5 \mathrm{mg} \mathrm{kg}^{-1}$; Tang, 2006), although compared with concentrations of $\mathrm{Cr}$ in soil, the accumulation of $\mathrm{Cr}$ in shoots $(4.0 \mathrm{mg}$ $\mathrm{kg}^{-1}$ ) and roots $\left(4.9 \mathrm{mg} \mathrm{kg}^{-1}\right.$ ) were much lower. Several studies have shown that the concentrations of $\mathrm{Pb}$ in plants are very low, and most of the absorbed $\mathrm{Pb}$ remains in roots (Shen et al., 2002; Salazar and Pignata, 2014). The species in the present study, however, showed a significant accumulation of $\mathrm{Pb}$. The concentrations of $\mathrm{Pb}$ in belowground biomass were $32.1 \mathrm{mg} \mathrm{kg}^{-1}$, similar to the level of soil $\mathrm{Pb}\left(32.9 \mathrm{mg} \mathrm{kg}^{-1}\right)$ and 10.7 -fold greater than the maximum allowable concentrations of $\mathrm{Pb}$ for normal growth of plants (0.1-3 mg kg-1; Shen et al., 2002). The concentrations of $\mathrm{Pb}$ in aboveground biomass were also high, with an average value of $15.5 \mathrm{mg} \mathrm{kg}^{-1}$, and were 7.8 -fold greater than the phytotoxicity limits of $\mathrm{Pb}$ in the aerial parts $\left(2 \mathrm{mg} \mathrm{kg}^{-1}\right.$; Shen et al., 2002). Concentrations of $\mathrm{As}, \mathrm{Cu}, \mathrm{Ni}$, and $\mathrm{Zn}$ in studied plants were within the normal range compared with the normal

Table 2. Concentrations of trace elements (mean \pm SD) in the aboveground and belowground biomass of the studied plants in the Fenghe River in China.

\begin{tabular}{lccc}
\hline Element & $\begin{array}{c}\text { Aboveground } \\
\text { biomass }\end{array}$ & $\begin{array}{c}\text { Belowground } \\
\text { biomass }\end{array}$ & $p$ value \\
\hline & \multicolumn{2}{c}{$\mathrm{mg} \mathrm{kg}^{-1}$ - } & \\
$\mathrm{As}$ & $0.45 \pm 0.27$ & $0.64 \pm 0.36$ & $<0.01$ \\
$\mathrm{Cd}$ & $0.27 \pm 0.31$ & $0.31 \pm 0.31$ & $\mathrm{~ns}$ \\
$\mathrm{Cr}$ & $4.0 \pm 2.1$ & $4.9 \pm 2.8$ & $\mathrm{~ns}$ \\
$\mathrm{Cu}$ & $13.4 \pm 7.3$ & $14.2 \pm 9.6$ & $<0.05$ \\
$\mathrm{Hg}$ & $0.005 \pm 0.006$ & $0.047 \pm 0.039$ & $<0.001$ \\
$\mathrm{Ni}$ & $2.4 \pm 3.2$ & $2.7 \pm 2.0$ & $\mathrm{~ns}$ \\
$\mathrm{~Pb}$ & $15.5 \pm 13.0$ & $32.1 \pm 6.2$ & $<0.001$ \\
$\mathrm{Zn}$ & $34.1 \pm 22.6$ & $34.7 \pm 21.6$ & $\mathrm{~ns}$ \\
\hline
\end{tabular}

concentration of TEs for plant growth $\left(<1 \mathrm{mg} \mathrm{kg}^{-1}\right.$ for As, 5-20 $\mathrm{mg} \mathrm{kg}^{-1}$ for $\mathrm{Cu}, 1-10 \mathrm{mg} \mathrm{kg}^{-1}$ for $\mathrm{Ni}$, and $1-1000 \mathrm{mg} \mathrm{kg}^{-1}$ for $\mathrm{Zn}$ ) reported previously (Reeves et al., 1996; Tang, 2006).

\section{Enrichment Characteristics of Trace Elements in Dominant Species}

Figure 2 illustrates the $\mathrm{TC}$ and $\mathrm{BC}$ for studied elements. The average values of $\mathrm{BC}$ for $\mathrm{Cd}$ and $\mathrm{Zn}$ were 2.21 and 1.75 , indicating most dominant species could accumulate high levels of $\mathrm{Cd}$ and $\mathrm{Zn}$. The plants studied generally showed poor translocation of TE concentrations from roots to shoots, and their average values of TC ranged from 0.10 to 0.98 , except $\mathrm{Zn}$, which had an average value of TC of 1.19.

Concentrations of $\mathrm{Cd}, \mathrm{Cr}$, and $\mathrm{Pb}$ in most plant species exceeded phytotoxicity limits reported in the literature. For Cd, 12 species had higher concentration than the normal growth limits, especially for Chrysanthemum indicum L., Artemisia argyi, Phragmites communis, Polygonum hydropiper, and Portulaca oleracea, with BC values of $3.32,4.65,5.30,3.60$, and 7.40, respectively. The two species $A$. argyi and Chenopodium album L. could also transfer Cd effectively from roots to shoots, and their TC values were 1.2 and 1.3 , respectively. The concentration of $\mathrm{Mn}$ in the studied soil reached $611 \mathrm{mg} \mathrm{kg}^{-1}, 1.3$-fold greater than the background value. Ramos et al. (2002) indicated that Mn-enriched media could promote Cd uptake. This may be one of the reasons for high accumulation of $\mathrm{Cd}$ in the studied plants.

For $\mathrm{Cr}$, concentrations in aboveground and belowground biomass of the studied plants were all greater than the suggested value for plant growth. However, the $\mathrm{BC}$ values for $\mathrm{Cr}$ in the plants of this study were low, ranging from 0.03 to 0.11 . Except for C. album and $P$. oleracea, all species showed high levels of $\mathrm{Cr}$ in aboveground biomass. Specifically, Plantago depressa Willd., Oenanthe javanica (Blume) DC., and Poa annua L. were the three top species to transfer more $\mathrm{Cr}$ from roots to shoots ( $\mathrm{TC}>1.5$ ). Both $\mathrm{Cr}$ (III) and $\mathrm{Cr}$ (VI) enter plants by a passive mechanism, and poorly translocation to aerial parts have been found for most plants (Peralta-Videa et al., 2009). Our results indicated the potential use of $P$. depressa, $O$. javanica, and $P$. annua for phytoextraction of $\mathrm{Cr}$.

For $\mathrm{Pb}$, concentrations in all plant tissue exceeded the phytotoxicity limits. There were 9 species showing a strong ability to accumulate and transfer $\mathrm{Pb}$. Species $P$. hydropiper, Setaria viridis (L.) P. Beauv., and $P$. oleracea were the three top species to accumulate $\mathrm{Pb}$, with high $\mathrm{BC}$ levels of $1.26,1.42$, and 1.25 , respectively. C. indicum, Bidens pilosa L., and P. oleracea showed strong translocation of $\mathrm{Pb}$ from roots to shoots, and their TC values were 1.11, 0.96, and 1.24, respectively. Plants do not have channels for $\mathrm{Pb}$ uptake, and most of the absorbed $\mathrm{Pb}$ remains in belowground biomass (Peralta-Videa et al., 2009). Several studies have shown that the $\mathrm{Pb}$ hyperaccumulators occupy the niche in low pH conditions (Shen et al., 2002; Tang, 2006). The Fenghe River ecosystem had an alkaline environment with a mean soil $\mathrm{pH}$ value of 8.2, water $\mathrm{pH}$ of 8.5, and sediment $\mathrm{pH}$ of 8.5, respectively. Based on the literature, accumulation of $\mathrm{Pb}$ in the studied species should not be significant. However, high accumulation and translocation of $\mathrm{Pb}$ were found in our study, suggesting the potential use of these species in phytoremediation.

Trace elements accumulation varied with species (Ali et al., 2013). Based on hierarchical cluster analysis, the studied species 

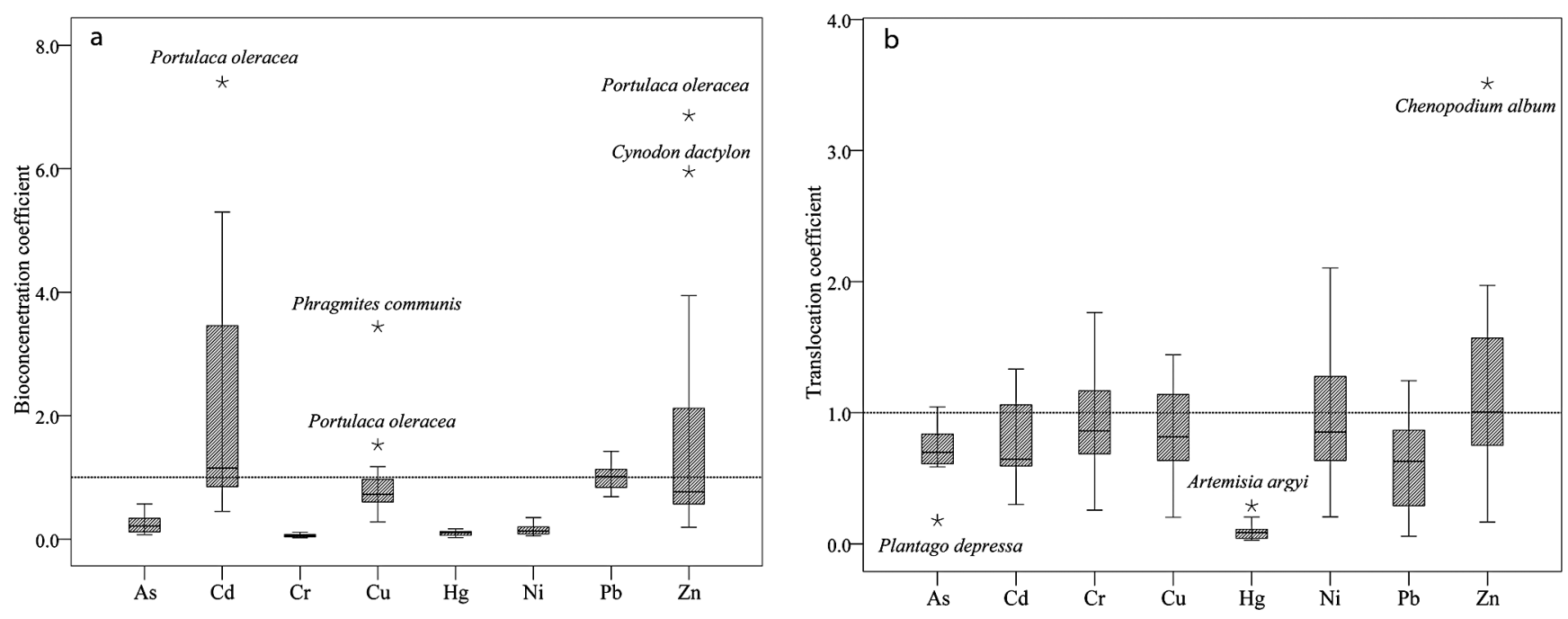

Fig. 2. Bioconcentration coefficient (a) and transformation coefficient (b) for trace elements ( $\mathrm{As}, \mathrm{Cd}, \mathrm{Cr}, \mathrm{Cu}, \mathrm{Hg}, \mathrm{Ni}, \mathrm{Pb}$, and $\mathrm{Zn}$ ) in the studied plant species in the Fenghe River system.

could be classified into four types (Fig. 3). Group I included $P$. communis and $P$. hydropiper, with a significant accumulation of $\mathrm{Cd}, \mathrm{Cr}, \mathrm{Hg}$, and $\mathrm{Pb}$. Species P. oleracea could concentrate high levels of $\mathrm{Cr}, \mathrm{Cd}, \mathrm{Pb}$ and $\mathrm{Cu}$, which belonged to Group II. Only A. argyi belonged to Group IV, with greater concentrations of As, $\mathrm{Cd}, \mathrm{Cr}, \mathrm{Cu}, \mathrm{Ni}$, and $\mathrm{Zn}$. The remaining species were affiliated with Group III. In general, $\mathrm{BC}<1$ indicates an excluder species, $\mathrm{BC}>1$ indicates an accumulator species, and $\mathrm{BC}>10$ indicates a hyperaccumulator species. Most researchers use the enrichment levels of $100 \mathrm{mg} \mathrm{kg}^{-1}$ for $\mathrm{Cd}, 1000 \mathrm{mg} \mathrm{kg}^{-1}$ for $\mathrm{As}, \mathrm{Cr}, \mathrm{Cu}, \mathrm{Pb}$, and $\mathrm{Ni}$, and $10,000 \mathrm{mg} \mathrm{kg}^{-1}$ for $\mathrm{Zn}$ as criteria for defining TE hyperaccumulation (Brooks et al., 1977; Tang, 2006; Salazar and Pignata, 2014). Van der Ent et al. (2013) proposed an additional hyperaccumulation threshold standard at a level of at least one order of magnitude greater than the normal range in plant tissues on noncontaminated areas. Taking these into account, none of the studied species fitted into the criteria of hyperaccumulators, most of them were accumulators, and few belonged to the excluders. With broad ecological amplitudes, P. oleracea, A. argyi, P. communis, and $P$. hydropiper, could accumulate and transfer more TEs. These four native species could grow well under dry conditions and can tolerant very high TE concentrations. These characteristics made them candidates for phytoremediators and biomonitors.

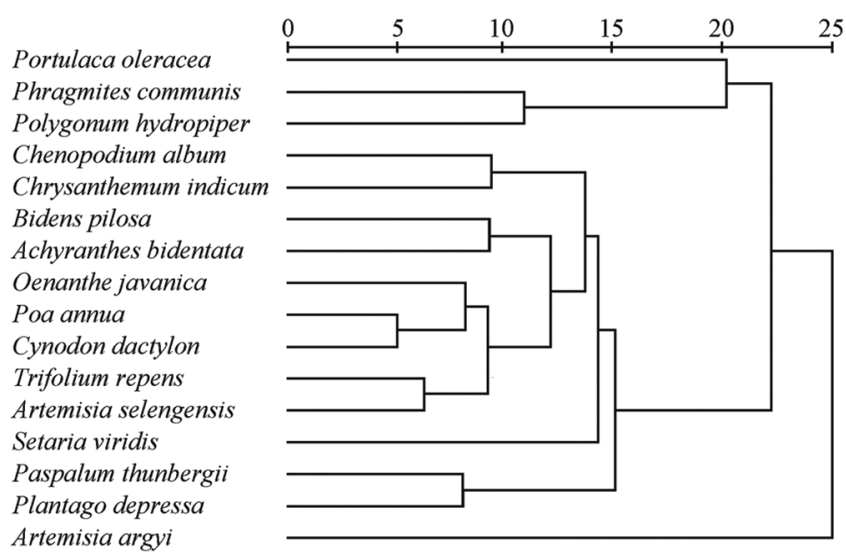

Fig. 3. Cluster analysis for the dominant plant species according to accumulation of trace elements.

\section{Relations of Trace Elements to Environmental Factors}

Because of chemical exchanges in the river ecosystem, interaction may exist between concentrations of TEs in plants and other factors including the concentrations of TEs in aquatic systems, hydrological indices, water quality, chemical properties of sediment and soil, and plant diversity (Rai 2008; Fu et al., 2014). Results of correlation analysis showed significant correlations between element concentrations within aboveground and belowground biomass $(r=0.506-0.933$; Supplemental Table S5). Furthermore, the element concentrations of $\mathrm{Cd}$ in belowground biomass showed significant correlations with As in belowground biomass $(r=0.744, p<0.01), \mathrm{Cr}$ in belowground biomass $(r=0.704, p<0.01), \mathrm{Hg}$ in belowground biomass $(r$ $=0.589, p<0.01), \mathrm{Pb}$ in belowground biomass $(r=0.519, p<$ $0.05)$, and $\mathrm{Zn}$ in belowground biomass $(r=0.603, p<0.01)$, possibly indicating a synergistic uptake between $\mathrm{Cd}$ and $\mathrm{As}, \mathrm{Cu}, \mathrm{Hg}$, $\mathrm{Pb}$ in the studied species.

Significant correlations between aboveground and belowground biomass for different elements were also found. The concentration of As in aboveground biomass correlated with $\mathrm{Cd}$ in belowground biomass $(r=0.743, p<0.01)$ and with $\mathrm{Zn}$ in belowground biomass $(r=0.734, p<0.01)$. The concentration of $\mathrm{Cd}$ in aboveground biomass correlated with As in belowground biomass $(r=0.589, p<0.01)$, with $\mathrm{Cr}$ in belowground biomass $(r=0.762, p<0.01)$, and with $\mathrm{Hg}$ in belowground biomass $(r=$ $0.701, p<0.01)$. The concentration of $\mathrm{Zn}$ in aboveground biomass correlated with $\mathrm{Cu}$ in belowground biomass $(r=0.769, p<$ $0.01)$ and with $\mathrm{Ni}$ in belowground biomass $(r=0.808, p<0.01)$. These TEs may demonstrate a synergistic effect on element transfer from roots to shoots.

Correlations between TE concentrations in plants and other environmental media were also analyzed. Generally, TE concentrations in the dissolved phase or the particulate phase of water showed little correlation with TE concentrations in plant biomass. Yet, $\mathrm{Cr}$ in the dissolved phase was correlated with $\mathrm{Cu}$ in belowground biomass $(r=-0.508, p<0.05), \mathrm{Cd}$ in the particular phrase was correlated with $\mathrm{Zn}$ in belowground biomass $(r=$ $0.592, p<0.01), \mathrm{Zn}$ in the dissolved phase was correlated with $\mathrm{Hg}$ in belowground biomass $(r=-0.587, p<0.01)$, and $\mathrm{Cu}$ in 
the particulate phase was correlated with $\mathrm{Ni}$ in belowground biomass $(r=0.624, p<0.01)$.

Element concentrations in sediments showed a poor relationship with TE concentrations in plants. However, $\mathrm{Cu}$ in sediments was correlated with $\mathrm{Cu}$ in belowground biomass $(r=0.543, p$ $<0.05)$ and with $\mathrm{Ni}$ in belowground biomass $(r=0.801, p<$ $0.01), \mathrm{Cd}$ in sediments was correlated with $\mathrm{Hg}$ in belowground biomass $(r=0.553, p<0.05), \mathrm{Hg}$ in sediments was correlated with $\mathrm{Hg}$ in belowground biomass $(r=0.775, p<0.01)$, and As in sediments was correlated with $\mathrm{Hg}$ in belowground biomass $(r=0.488, p<0.01)$. Many studies have revealed that the total element concentration in soil is a significant variable that influences the accumulation of TEs in plants (Rascio and Navari-Izzo, 2011; Salazar and Pignata, 2014). In this study, concentrations of TEs in plants were highly comparable with those in the soil, even though the plant species varied. There were positive correlations between soil element concentration and TE concentrations in plants $(r=0.501-0.961$; Supplemental Table S6). In particular, increased concentrations of $\mathrm{Cd}$ in soil facilitated the uptake of $\mathrm{Cd}$ and $\mathrm{Zn}$ by plants. Soil $\mathrm{Pb}$ increased the enrichment of $\mathrm{Zn}$ and $\mathrm{Pb}$ in roots, whereas elevated soil $\mathrm{Zn}$ could promote the accumulation of $\mathrm{Cd}$ and $\mathrm{Hg}$ in the studied plants.

Hydrological indices showed no correlations with TE concentrations in plants while the water quality indices showed a close relationship with the plant element concentrations (Supplemental Table S7). For instance, there were correlations between $\mathrm{NO}_{3}-\mathrm{N}$ and $\mathrm{Ni}$ in belowground biomass $(r=-0.552, p$ $<0.01)$, between $\mathrm{NH}_{3}-\mathrm{N}$ and As in belowground biomass $(r=$ $-0.495, p<0.05)$, between TP and Cd in belowground biomass $(r=0.534, p<0.05)$, and between chemical oxygen demand and $\mathrm{Hg}$ in belowground biomass $(r=0.569, p<0.01)$. Among the chemical properties of sediment and soil, only soil $\mathrm{pH}$ showed significant correlations with accumulation of As in belowground biomass $(r=0.561, p<0.01)$, Cd in belowground biomass $(r=$ $0.591, p<0.01), \mathrm{Cu}$ in belowground biomass $(r=-0.464, p<$ $0.05), \mathrm{Hg}$ in belowground biomass $(r=0.484, p<0.05)$, and $\mathrm{Zn}$ in belowground biomass $(r=0.443, p<0.05)$.

Further analyses were conducted to identify the key factors influencing the enrichment of TEs in plants. Based on the canonical corresponding analysis, soil $\mathrm{pH}$ showed the highest sensitivity for the first direction $(\mathrm{Cr})$ and the second direction (As, $\mathrm{Cd}, \mathrm{Hg}, \mathrm{Pb}$ and $\mathrm{Zn}$ ) while soil organic matter was not associated with these elements in plants (Fig. 4a). Commonly, acidic soil $\mathrm{pH}$ and soil organic matter influences the solubility of soil elements and thus affects the rate of TE uptake by plants (Kirkham, 2006; Salazar and Pignata, 2014). Considering the slightly alkaline nature of the soils studied and that soil $\mathrm{pH}$ values were closely related to the concentration of TEs in soil, soil $\mathrm{pH}$ was not appropriate to explain the difference found for the accumulation of TEs in plants. In addition, plant abundance showed a negative correlation with As in belowground biomass $(r=-0.490, p<0.05)$, Cd in belowground biomass $(r=-0.497$, $p<0.05)$, and $\mathrm{Pb}$ in belowground biomass $(r=-0.587, p<$ $0.01)$ to indicate that an increase in concentration of certain TEs could lead to a decline in biodiversity of plants (Fig. 4a) in agreement with several studies (Rascio and Navari-Izzo, 2011; Fu et al., 2014). Furthermore, results of the canonical corresponding analysis showed chemical oxygen demand in the water had significant impacts on accumulation of $\mathrm{Hg}$ and $\mathrm{Pb}$ in plants, while $\mathrm{TN}, \mathrm{TP}, \mathrm{NH}_{3}-\mathrm{N}$, and $\mathrm{NO}_{3}-\mathrm{N}$ were closely related to accumulation of $\mathrm{As}, \mathrm{Cd}$, and $\mathrm{Zn}$ in plants (Fig. 4b). These results suggested that in accordance with the discharge of domestic and industrial sewage, TEs were co-released to the ecosystem and resulted in accumulation of TEs in plants.

\section{Conclusions}

A systemwide investigation of TE pollution in the Fenghe River ecosystem was conducted. Enriched concentrations of TEs in sediment and riparian soil were found in the midstream and downstream regions. The high levels of elements in the study area caused moderate risk and further attention should be given to $\mathrm{Cd}$. Most dominant species with large biomass were characterized as accumulators and could accumulate large concentrations of TEs in dry conditions. Four species of plants, $P$. oleracea, $A$. argyi, $P$. communis, and $P$. hydropiper, could be suitable as biomonitors or phytoremediators of TEs in the study area. It appeared that a combination of factors affected TE concentrations in the studied plants. Concentrations of TEs in soil were found to be the
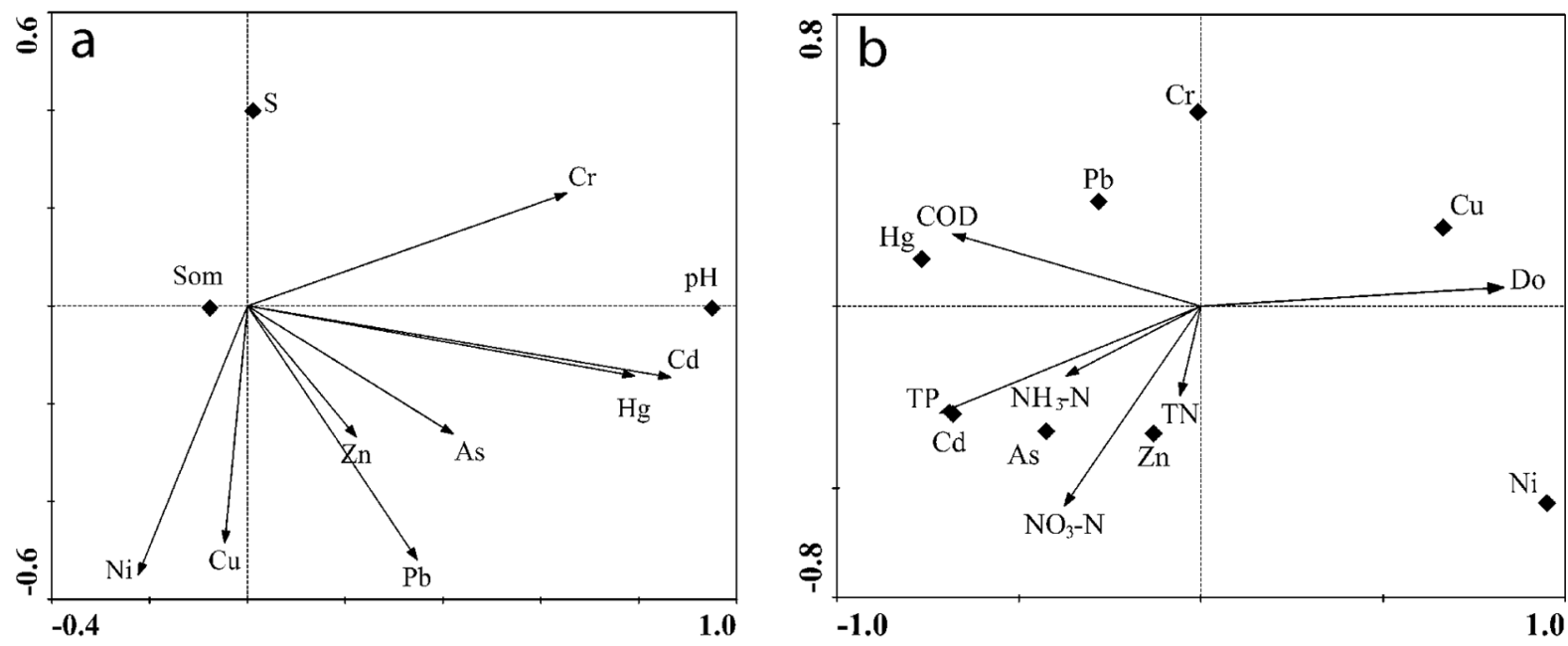

Fig. 4. Canonical corresponding analysis biplot of trace elements in plants and (a) soil pH, soil organic matter, and plant abundance (S, Shannon-Weiner diversity index; Som, soil organic matter); and (b) water quality indices (COD, chemical oxygen demand; Do, dissolved oxygen). Permutation was evaluated with Monte Carlo test and the significances of all canonical axes were achieved $(p<0.05)$. 
dominant factor influencing the concentrations of TEs in plants, and soil $\mathrm{pH}$ was also a major factor. The co-release behavior of major pollutants of chemical oxygen demand, TN, and TP and trace elements led to the pollution of the river system, and TE accumulation in plants. The connection between plant element concentrations and environmental conditions could co-reflect the pollution status of the river ecosystem.

\section{Acknowledgments}

We gratefully acknowledge support for this research from the National Natural Science Foundation of China (grant no. 41030744).

\section{References}

Ali, H., E. Khan, and M.A. Sajad. 2013. Phytoremediation of heavy metalsConcepts and applications. Chemosphere 91:869-881. doi:10.1016/j. chemosphere.2013.01.075

Awadallah, R.M., M.E. Soltan, and M.N. Rashed. 1996. Relationship between heavy metals in mud sediments and beach soil of the river Nile. Environ. Int. 22:253-258. doi:10.1016/0160-4120(96)00010-4

Bai, J.H., R. Xiao, K.J. Zhang, and H.F. Gao. 2012. Arsenic and heavy metal pollution in wetland soils from tidal freshwater and salt marshes before and after the flow-sediment regulation regime in the Yellow River delta, China. J. Hydrol. 450-451:244-253. doi:10.1016/j.jhydrol.2012.05.006

Brooks, R.R., J. Lee, R.D. Reeves, and T. Jaffré. 1977. Detection of nickeliferous rocks by analysis of herbarium specimens of indicator plants. J. Geochem. Explor. 7:49-57. doi:10.1016/0375-6742(77)90074-7

Fu, J., C. Zhao, Y. Luo, C. Liu, G.Z. Kyzas, Y. Luo, D.Y. Zhao, S.Q. An, and H. Zhu. 2014. Heavy metals in surface sediments of the Jialu River, China: Their relations to environmental factors. J. Hazard. Mater. 270:102-109. doi:10.1016/j.jhazmat.2014.01.044

He, F.L., J.V. LaFrankie, and B. Song. 2002. Scale dependence of tree abundance and richness in a tropical rain forest, Malaysia. Landscape Ecol. 17:559568. doi:10.1023/A:1021514104193

Kalender, L., and S.C. Uçar. 2013. Assessment of metal contamination in sediments in the tributaries of the Euphrates River, using pollution indices and the determination of the pollution source, Turkey. J. Geochem. Explor. 134:73-84. doi:10.1016/j.gexplo.2013.08.005

Kirkham, M.B. 2006. Cadmium in plants on polluted soils: Effects of soil factors, hyperaccumulation, and amendments. Geoderma 137:19-32. doi:10.1016/j.geoderma.2006.08.024

Lasheen, M.R., and N.S. Ammar. 2009. Speciation of some heavy metals in river Nile sediments, Cairo, Egypt. Environmentalist 29:8-16. doi:10.1007/ s10669-008-9175-3

Leung, H.M., Z.H. Ye, and M.H. Wong. 2007. Survival strategies of plants associated with arbuscular mycorrhizal fungi on toxic mine tailings. Chemosphere 66:905-915. doi:10.1016/j.chemosphere.2006.06.037

Lu, R.K. 2000. Agriculture chemical analysis of soil. Chinese Agriculture Technology Press, Beijing.

MathWorks. 2012. Matlab release 7.14. MathWorks, Natick, MA.

Nie, M., N. Xian, X. Fu, X. Chen, and B. Li. 2010. The interactive effects of petroleum-hydrocarbon spillage and plant rhizosphere on concentrations and distribution of heavy metals in sediments in the Yellow River delta, China. J. Hazard. Mater. 174:156-161. doi:10.1016/j.jhazmat.2009.09.030

Niu, H., W. Deng, Q. Wu, and X. Chen. 2009. Potential toxic risk of heavy metals from sediment of the Pearl River in South China. J. Environ. Sci. (China) 21:1053-1058. doi:10.1016/S1001-0742(08)62381-5

Osman, A.G.M., and W. Kloas. 2010. Water quality and heavy metal monitoring in water, sediments, and tissues of the African catfish Clarias gariepinus (Burchell, 1822) from the river Nile, Egypt. J. Environ. Prot. 1:389-400. doi:10.4236/jep.2010.14045

Ouyang, T.P., Z.Y. Zhu, Y.Q. Kuang, N.S. Huang, J.J. Tan, G.Z. Guo, and B. Sun. 2006. Dissolved trace elements in river water: Spatial distribution and the influencing factor, a study for the Pearl River delta economic zone, China. Environ. Geol. 49:733-742. doi:10.1007/s00254-005-0118-8

Pandey, V.C. 2015. Assisted phytoremediation of fly ash dumps through naturally colonized plants. Ecol. Eng. 82:1-5. doi:10.1016/j.ecoleng.2015.04.002

Pandey, V.C., D.N. Pandey, and N. Singh. 2015. Sustainable phytoremediation based on naturally colonizing and economically valuable plants. J. Clean. Prod. 86:37-39. doi:10.1016/j.jclepro.2014.08.030

Peet, R.K. 1975. Relative diversity indices. Ecology 56:496-498. doi: $10.2307 / 1934984$
Peralta-Videa, J.R., M.L. Lopez, M. Narayan, G. Saupe, and J. Gardea-Torresdey. 2009. The biochemistry of environmental heavy metal uptake by plants: Implications for the food chain. Int. J. Biochem. Cell Biol. 41:1665-1677. doi:10.1016/j.biocel.2009.03.005

Ramos, I., E. Esteban, J.J. Lucena, and A. Gárate. 2002. Cadmium uptake and subcellular distribution in plants of Lactuca sp. Cd-Mn interaction. Plant Sci. 162:761-767. doi:10.1016/S0168-9452(02)00017-1

Rai, P.K. 2008. Heavy metal pollution in aquatic ecosystems and its phytoremediation using wetland plants: An ecosustainable approach. Int. J. Phytorem. 10:133-160. doi:10.1080/15226510801913918

Rascio, N., and F. Navari-Izzo. 2011. Heavy metal hyperaccumulating plants: How and why do they do it? And what makes them so interesting? Plant Sci. 180:169-181. doi:10.1016/j.plantsci.2010.08.016

Reeves, R.D., A.J.M. Baker, A. Bgrhidi, and R. Berazain. 1996. Nickel-accumulating plants from the ancient serpentine soils of Cuba. New Phytol. 133:217-224. doi:10.1111/j.1469-8137.1996.tb01888.x

Riccobono, F., G. Perra, A. Pisani, and G. Protano. 2011. Trace element distribution and $235 \mathrm{U} / 238 \mathrm{U}$ ratios in Euphrates waters and in soils and tree barks of Dhi Qar province (southern Iraq). Sci. Total Environ. 409:3829_ 3838. doi:10.1016/j.scitotenv.2011.06.048

Salazar, M.J., and M.L. Pignata. 2014. Lead accumulation in plants grown in polluted soils. Screening of native species for phytoremediation. J. Geochem. Explor. 137:29-36. doi:10.1016/j.gexplo.2013.11.003

SEPAC (State Environmental Protection Administration of China). 1990. Total station of China environment monitoring, Chinese soil element background values. China Environment Science Press, Beijing. p. 342-381.

SEPAC (State Environmental Protection Administration of China). 2002. Chinese environmental quality standards for surface water (GB3838-2002). (In Chinese.) Available at China Water Risk, Hong Kong. http://chinawaterrisk.org/research-reports/environmental-quality-standards-for-surfacewater-gb3838-2002/ (accessed 14 Mar. 2016).

Shen, Z.G., X.D. Li, C.C. Wang, and H.M. Chen. 2002. Lead phytoextraction from contaminated soils with high-biomass plant species. J. Environ. Qual. 31:1893-1900. doi:10.2134/jeq2002.1893

Simpson, E.H. 1949. Measure of diversity. Nature 163:668.

Singh, M., G. Müller, and I. Singh. 2003. Geogenic distribution and baseline concentration of heavy metals in sediments of the Ganges River, India. J. Geochem. Explor. 80:1-17. doi:10.1016/S0375-6742(03)00016-5

Singh, V.K., K.P. Singh, and D. Mohan. 2005. Status of heavy metals in water and bed sediments of river Gomti-A tributary of the Ganga river, India. Environ. Monit. Assess. 105:43-67. doi:10.1007/s10661-005-2816-9

Song, Y., J. Ji, Z. Yang, X. Yuan, C. Mao, R.L. Frost, and G.A. Ayoko. 2011. Geochemical behavior assessment and apportionment of heavy metal contaminants in the bottom sediments of lower reach of Changjiang River. Catena 85:73-81. doi:10.1016/j.catena.2010.12.009

Sun, B., F.J. Zhao, E. Lombi, and S.P. McGrath. 2001. Leaching of heavy metals from contaminated soils using EDTA. Environ. Pollut. 113:111-120. doi:10.1016/S0269-7491(00)00176-7

Tang, S.R. 2006. The theory and method to restore the polluted environment by plants. China Science Press, Beijing.

Ter Braak, C.J.F., and P. Smilauer. 2002. Canoco for Windows version 4.5. Biometris-Plant Research International, Wageningen, the Netherlands.

Van der Ent, A., A.J. Baker, R.D. Reeves, A.J. Pollard, and H. Schat. 2013. Hyperaccumulators of metal and metalloid trace elements: Facts and fiction. Plant Soil 362:319-334. doi:10.1007/s11104-012-1287-3

Wang, D., Y. He, J. Liang, P. Liu, and P. Zhuang. 2013. Distribution and source analysis of aluminum in rivers near Xi'an City, China. Environ. Monit. Assess. 185:1041-1053. doi:10.1007/s10661-012-2612-2

Wang, Y., P. Chen, R. Cui, W. Si, Y. Zhang, and W. Ji. 2010. Heavy metal concentrations in water, sediment, and tissues of two fish species (Triplobysa pappenheimi, Gobio hwanghensis) from the Lanzhou section of the Yellow River, China. Environ. Monit. Assess. 165:97-102. doi:10.1007/ s10661-009-0929-2

Wong, S.C., X.D. Li, G. Zhang, S.H. Qi, and Y.S. Min. 2002. Heavy metals in agricultural soils of the Pearl River Delta, South China. Environ. Pollut. 119:33-44. doi:10.1016/S0269-7491(01)00325-6

Yi, Y., Z. Yang, and S. Zhang. 2011. Ecological risk assessment of heavy metals in sediment and human health risk assessment of heavy metals in fishes in the middle and lower reaches of the Yangtze River basin. Environ. Pollut. 159:2575-2585. doi:10.1016/j.envpol.2011.06.011

Zhao, Y.C., Z.G. Wang, and W.X. Sun. 2010. Spatial interrelations and multiscale sources of soil heavy metal variability in a typical urban-rural transition area in Yangtze River Delta region of China. Geoderma 156:216-227. doi:10.1016/j.geoderma.2010.02.020 